\title{
Assessment Concept of Geographical Skills on Senior High School in Indonesia
}

\author{
Yuli Astuti* \\ Geography Education Department, Postgraduate School Universitas Pendidikan Indonesia, Bandung, Indonesia \\ *Corresponding author: geoyuli@student.upi.edu
}

\begin{abstract}
This paper aims to discuss the theory and practice of assessment of the results of geography learning at the senior high school in Indonesia. Geography consists of three components, the subject matter studied, skills, and perspectives. The subject matter learned in geography is a summary of the essential knowledge, is the foundation of standard geography. This subject matter is the basis of the use of the skills of geography. Geography education is the application of geography in education. Based on the syllabus curriculum, the principle of assessment used in the subjects of geography is based on class or authentic. In general when examined, geography skills with the learning process of the curriculum there is conformity between learning outcomes assessment of theoretical subjects of geography in Indonesia is in compliance or already measure aspects of geography skills. Based on several researches in terms of practice, geography skills assessment of learners on the subjects of geography in Indonesia is affected by the competence of teachers, the learning models applied by the teachers, learning materials are used, as well as the motivation of the teachers to the students related the importance of mastering the skills of geography.
\end{abstract}

Keywords: geography, skills assessment, senior learning high school, curriculum, learning geography, Indonesia

Cite This Article: Yuli Astuti, “Assessment Concept of Geographical Skills on Senior High School in Indonesia.” American Journal of Educational Research, vol. 5, no. 7 (2017): 879-886. doi: 10.12691/education-5-8-7.

\section{Introduction}

In English, education is derived from two words in Latin that "educare (educere)" which means training or print and "educatum" meaningful action to teach, or it can be said that education is the process of the development of hidden talents of the children, at which time the child did not know his ability, therefore here the role of teachers to know and use the most suitable method to improve these talents. Education is derived from the development of the child in it [1].

Education is a process of living through sustainable reconstruction experience. The development process for all abilities of individuals which will make the individual will be able to control their environment and maximize its ability [1]. Education as a process of educating or teaching that aims to develop the knowledge, skills or character [2].

The education process associated with the activity and the way that diverse thinking and aims to shape the behavior of people who are educated [3]. It should be understood, basically, it is not easy to be able to accommodate the needs of individual learners in the educational process, including the assessment process. For that process must have an assessment carried out the principles of justice, equality and objectivity is high. Assessment is one part of a class activity which is one of the fundamental processes necessary to raise the level of learning and aim to determine the increase of learners. When learners know and understand these principles, the quality of learning will increase [4]. Assessment is an important part of learning. A good assessment included influenced by the teaching style, strengths, and needs. It's flexible and reflects the achievement of learners in the learning [5].

Assessment is a process of gathering information used to determine the ability of the students, the basis for making a decision about the students, curriculum, programs and schools and school policies [6,7]. Assessing the activities can be said when educators gather information to assist in making decisions related to the achievement of learners. Assessment of education in elementary education and secondary education consists of learning outcomes assessment by educators; education units; government. Assessment of learning outcomes of students in primary education and secondary education includes aspects of attitude; knowledge; and skills. Assessment of learning outcomes by educators aims to monitor and evaluate the process, learning progress, and improvement of learning outcomes of students on an ongoing basis. Assessment of learning outcomes by educational units aimed to assess the achievement of graduate competency standards for all subjects.

Assessment of learning outcomes by the government aimed to assess the achievement of national competency on specific subjects. The guiding principle in assessing, according to that is as follows: 1 . The purpose of learning is to be assessed should be clear, 2 . ensure valuation techniques selected in accordance with the purpose of learning, 3. ensuring that assessment techniques are selected according to the needs of teachers, 4 . if possible, better to use an indicator that many in every achievement of learning objectives, 5 . ensure when teachers interpret 
the results of the assessment of students, the results are in accordance with the ability of learners [6].

Geography consists of three components that are interconnected and can not be separated from one another that are the subject matter being studied, skills, and perspectives [8]. Subject matter learned in geography is a summary of the essential knowledge and is the foundation of standard geography.

Geography skills consist of (1) asking geographic questions, (2) acquiring geographic information, (3) organizing geographic information, (4) analyzing geographic information, and (5) answering geographic questions. Knowledge and ability is considering two aspects of the spatial and environmental. Since the early 20th century a variety of changes has occurred in geography, both in terms of geography as a science academic, educational theory, and in the educational structure, changes are ongoing.

The most significant development of geography in education was in 1991 at the time of the enactment of the National Geography Curriculum (NGC) [9]. Even geographers have its own views related to geography should be taught in school, geography curriculum should be structured in such a way as to support the achievement of the common objectives of education and type of school in question [10]. Geography education is the application of geography in education.

The function of geography is to develop knowledge about patterns of spatial and related process, develop basic skills in obtaining data and information, communicate and implement geographic knowledge, and fosters attitudes, awareness, and concern for the environment and resources as well as the tolerance of social and cultural diversity [11].

Geography as the study of the causal relationship of symptoms and events in the earth's surface is an important subject that can contribute to overcoming the problems of the world [12]. In some countries, geography has placed as the core subjects and has helped many decision-making processes in development. According to Grovenor [13], humans are closely related to geography in daily life.

Every human being occupies a place with certain characteristics and interacts with its environment. Knowledge and skills of geography are very important in understanding the activities and patterns in life. In Indonesia, the geography is given to basic education as an integral part of Social Science and given in secondary education as a separate subject.

Social Science became one of the subjects in basic education, while in senior high school Social Science known as the specialization together with specialization in mathematics and science; language and culture. Social science in basic education, especially primary schools, are therefore integrated-integrated thematic learning. At the level of high school competencies expected after students learn geography in accordance curriculum revision is able to conduct research in critical, creative, and innovative about the environment and the people within the local, national and global to solve the problem in accordance with the approach of the social sciences and humanities scientifically, and communicating through technology with academic ethics [12].

As noted previously geography learning outcomes assessment should be made by educators aim to monitor and evaluate the process, learning progress, and improvement of learning outcomes of students in the subject of geography simultaneously. Based on the research of Daryoko [14] and Mintowati [14] explains that in a geography lesson, students only use the book as a primary learning resource.

Teachers are not emphasis on achieving geography skills. This is not in accordance with the rules [15] which require the power of the curriculum in Indonesia to develop competence achievement learning experience by providing opportunities for students to develop the ability to act, knowledgeable, skilled, and act. Consequently, geography skills of learners are still considered low.

Though geography skills are very useful when we will make decisions such as where we will live, where we will work, in school, build a house, and others. In fact in Indonesia can we know that the number of decisions related to land use changes should not have caused disasters such as floods, forest fires, extinction of flora and fauna, pollution, and a variety of adverse impacts to humans and the environment.

Acquisition of skills geography meaning lies in its application to the situation and address the challenges and problems faced learners [16]. Based on this background, the authors are interested in making the text discusses the theory and practice of assessment of geography learning at the high school in Indonesia, especially in terms of geography skills.

\subsection{Study Question}

To achieve the aim objective of this study, the research questions examine:

- How the concept of geography skills?

- How the concept of assessment of geography in Indonesia learning conceptually and in practice?

- How geography skills mastery learners?

- Whether the assessment of learning geography in Indonesia has been able to measure the skills of geography?

\section{Methodology}

The study describes the concept and practice of geography learning assessment and how the level of mastery of skills geography learners and what factors influence it. Data collection using literature review and analysis data from several researches Based on data that has been collected, themes discussed included: the concept of geography \& judgment skills, concepts and assessment practices in Indonesia, correspondence between geography with skills assessment geography.

\section{Geography Skills Concepts}

The common definition of geography is a description of the Earth's surface [17]. Geography is a high-level science system development on the environment [18]. Geography covers the science of physical phenomena on earth, human, and economic activity, social history.

Geography covering all topics such as the natural environment, community, cultural knowledge, place, and 
distance, economic, political, physical, atmospheric, literature related to the place and culture as a result of its surroundings, maps and measurements of the spatial distribution and relationship [19]. Geography is one of the oldest sciences in the world such as math, history or philosophy [18].

The tendency to record certain phenomena encourages the formation chorology and regional geography. At the same time, scientists are discovering and explaining the differences and similarities between the phenomena of geography and began to categorize and classify the facts of geography becomes systematic. Gradually geography evoluted likes geology and biology into separate disciplines.

Geography skills are tools and techniques needed by a person to think of geography, or it can be said geography skills as a special approach that is used to understand the patterns and processes of both physical and human on earth. Related studies geography skills in learning and more widespread application made especially starting in the 1960s, including that conducted by researchers The United States and Britain. National Geography Standards have an important role in the application of geography in learning at a rate of 4, 8 and 12 [20]. There are five components geography skills as follows [8]:

\subsection{Asking Geographic Questions}

This ability is related to the ability and the desire to ask questions, speculate and answer the statement of why something exists somewhere, and why they were there. Learners are expected to be able to ask questions about where the location? Why there? The phenomenon of what is associated with it? Learners are asked to speculate about the answer to answer possible questions. The hypothesis of this speculation will encourage students to search for information. Geography distinguishes themselves with other sciences in question "where" and "why". This capability is particularly important for learners to develop and practice it as well in order to distinguish the geographic and nongeographic questions. At a higher level, learners will be able to identify the problem and find solution geography.

\subsection{Acquiring Geographic Information}

Geographic information is information about the location, the characteristics of the physical and human conditions of the location and condition of people living in the region. To answer the statement geography, learners gather information from various sources, both are interpreted maps, primary and secondary data, interviews, field work, or library reference. The ability to obtain geographic information including show locations, collecting data, observation and recording information systematically, reading and interpreting maps and representations of space and other places, interviews and using statistical methods. Primary data especially data obtained from field checks by learners is an important discovery data. The fieldwork will involve learners in distributing questionnaires, taking pictures regarding the location and what's in place of activity, recording, interviews and collect samples. The fieldwork will raise the curiosity of students and make learning more fun and relevant geography.

\subsection{Organizing Geographic Information}

The data that has been collected is organized or arranged and presented for analysis and interpretation. Data should be compiled systematically. Creativity and the ability required to organize geographic information effectively. A wide variety of data types to be distinguished and classified, for example in the form of visual, charts, tables, maps and others.

\subsection{Analyzing Geographic Information}

This ability is related to looking for patterns, relationships, and interrelationships. Learners analyze and interpret information, related patterns, and processes. Furthermore, students can make a synthesis of observations that have been made. Analysis geography associated with various activities. Learners must be careful in interpreting the map for the information contained in it and compare the spatial patterns and their relationship, analysis tables, and graphs to identify trends and relationships between them, using statistical data to identify trends, relationships, and interactions. These activities will answer geography questions beforehand.

\subsection{Answering Geographic Questions}

Based on previous abilities that have been done, then the learner's ability to answer geography questions expected to be able to generalize from the findings. Generalization is the culmination of the proceedings. These geographic generalizations can be made on the basis of deductive and inductive approach. The inductive approach encourages students to download the synthesis of geographic information to answer geographic questions and make conclusions. The deductive approach encourages students to identify relevant questions, gather relevant data and decide which one matches generalize findings. Moreover, learners should also have good communication skills in answering geography questions and find out alternatives to achieve the generalization.

\section{Concept Assessment of Learning Geography in Indonesia}

Learning is functionally defined as a change in behavior as a result of the experience or mechanical changes in organisms including humans as a result of the process of planting experience [21]. Learning can be said to be an adaptation ontogenetic where changes in the behavior of the organism as a result of routine activities in the organism's environment.

Geography education geography is the application of science to the field of education. Geography education content consists of geographic knowledge, skills, and attitudes that enable learners in understanding the processes occurring in the environment or society in the world and to master the geographic literacy. 
Geographic literacy will influence the public understanding of the place, place, and action linkage spatial caused by various factors. Geography education is also developing and evaluating the curriculum, teaching and learning objectives, as well as the methodology concerning the learning process and the development of services geography teacher professionalism [22]. The function of geography is to develop knowledge about patterns of spatial and related process, develop basic skills in obtaining data and information, communicate and implement geographic knowledge, and fosters attitudes, awareness, and concern for the environment and resources and tolerance of social and cultural diversity [11].

Assessment is a systematic process for collecting data of learners in learning [23]. In designing the assessment, it is necessary to pay attention to factors such as the type of assessment, the conditions, and criteria in accordance with the common goals and the learning experience of students. Assessment can be formative or summative. The difference between summative assessments by formative assessment lies in the purpose of the assessment is used. One important element in the assessment of learning geography is to examine the extent to which the knowledge and skills of learners [24]. Here is the procedure for preparing the assessment of learning geography by [25]:

- Draw up the requirements needed,

- Using their own concepts,

- Draw up alternative plans,

- Determine the involvement of learners in ratings,

- Develop criteria and rules rating assessment,

- Establish procedures related results,

- Convey the results to students and parents as well as school parties and other interested parties,

- Evaluate and modify point to four linked determine the involvement of learners in the assessment is an important aspect.

Competencies assessed in learning geography, among others [25]:

- The ability to read different types of maps,

- The ability to explain the various patterns of regularity in astronomy, geography, social and economic,

- The ability to use the model and the instrument geography,

- The ability to make observations in a planned and systematic,

- The ability to read and utilize and create geographic data (statistical data, graphs, charts, and figures),

- The ability to make calculations (distance, elevation difference, average temperature, amplitude, temperature reduction when an increase in height, the time difference),

- The ability to use the vocabulary of terminology and graphic symbols in writing and in speech,

- Evaluating the human activity in the natural environment.

Geography learning outcomes assessment should not only measure the cognitive aspects but also other aspects such as affective aspects and geography skills. According to the International Geographic Union (IGU) [11] that sustainable development has become as mission Geography
Education in 2005 - 2014. Competence geography for sustainable development includes:

- Understanding and knowledge of geography; natural systems of the earth and the interaction between the components that make up the Earth system, socio-economic and spatial concepts,

- Geography skills such as communication, critical thinking, practical and social skills to explore topics of geography, both at the local level to the international,

- Attitudes and values; dedicated to solving the problem, both in local scale, regional and base on international human rights declarations.

Based on the revision of the curriculum syllabus [12], the principle of assessment used in the subjects of geography on is class-based or authentic. Rate-based classes have principles [26], namely:

1. Objective, based on a standard assessment and not be influenced by the subjectivity of the assessor.

2. Integrated, assessment is carried out in a planned, integrated with learning activities, and sustainable.

3. Economical, efficient and effective assessment in the planning, execution, and reporting.

4. Transparent, assessment procedures, assessment criteria, and basic decision-making accessible to all parties.

5. Accountable, meaning schools accountable to internal and external parties.

6. Educational, educate and motivate learners and teachers.

Assessment is processing to take the decision to increase the competence of learners well after going through the steps of planning, preparation of assessment tools, information collection, processing, and use of information about the learning outcomes of students. Assessment function is to measure the achievement of competence in the aspect of attitudes, knowledge, and skills. The following described aspects of the attitudes, knowledge, and skills are assessed [26].

1. Attitude aspects assessed in the learning process and results geography subjects are:

a. Attitudes and honest behavior, discipline, responsibility, caring, polite, responsive and pro-active).

b. Attitudes showed that learners become part of the solution to various problems in interacting effectively with the social and natural environment as well as in placing itself as a reflection of the nation in the association world.

c. Attitudes and behaviors patriotism, proud as a nation of Indonesia, and is responsible for the integrity of the Unitary Republic of Indonesia is based on Pancasila and the 1945 Constitution.

Assessment aspects of attitudes carried out through the following stages: observe and record the behavior of students during the learning process; following up on observations; and describe the behavior of learners.

2. Aspects of knowledge assessed in the learning process and results geography subjects include:

a. The depth of critical thinking in understanding, implementing, and analyzing factual knowledge, conceptual, procedural, and metacognitive on the object of study of geography. 
b. Ability to solve problems relation to the object of study of geography.

c. Creativity in the creation and proposed the idea to update the physical environment and the social environment as a resource.

Rate aspect of knowledge is done through the planning stages of assessment; developing assessment instruments; conducting the assessment; utilize the assessment results, and report the result in the form of a numbers and descriptions.

3. Aspects of the skills assessed in the learning process and results geography subjects include:

a. Ability to learn contextually as an integral part of understanding the problems of geography independent and sustainable.

b. The ability to collaborate and communicate to convey ideas and solutions to overcome.

c. Mastery of information technology, media, and communication (literacy) associated with the use of technology such as the management of geographic maps, remote sensing imagery and Geographic Information Systems (GIS).

Assessment skills aspect is done through the planning stages of assessment; developing assessment instruments; conducting the assessment; utilize the assessment results, and report the result in the form of a numbers and descriptions.

\section{Implementation and Reporting Assessment}

Implementation of the assessment carried out by the geography teacher for homeroom reported to serve as the next assessment report of the educational unit. The implementation stage of assessment is as follows [26].

1. At the beginning of the semester, educators analyze the syllabus that has been provided and set of indicators to be tested.

2. Develop grid (table specification) tests that contain subject matter that will be tested, levels of cognitive or behavioral aspects to be measured, and the determination of the number of test items for each aspect.

3. Teachers developing assessment instruments in accordance with core competencies, basic competencies, and indicators of competence that was previously set.

4. The teacher gives an explanation of the assessment criteria for each attitude that will be assessed include the form of the instruments to be used.

5. Checking and processing the results of the assessment with reference to the scoring guidelines and assessment criteria previously set.

6. Results of the assessment are informed to each student at any weekend with a view to (a) determine progress, (b) determine the competence of that yet and that has been achieved according to defined criteria, (c) motivate learners to improve their competence still low and trying to maintain competence has been good, and (d) be a reflection section for educators to improve learners' development strategy in the future.
7. Follow-up assessments every week as a basis to make the process of coaching and development.

8. At the end of the semester, each daily assessment score for a semester graphed development and set the final value of the average value of competence. The graph used as a reflection of the development of the learning process and coaching attitude. The average value of competence submitted to homeroom by every educator as grades.

\section{Correspondence between the Geography Skills Concept Learning Assessment in Accordance with the Curriculum of Geography Learning in Indonesia}

Geography skills consist of (1) asking geographic questions, (2) acquiring geographic information, (3) organizing geographic information, (4) analyzing geographic information, and (5) answering geographic questions. Generally, when examined aspects of geography skills with curriculum learning process which consisted of observing, ask, try, associate/processing, communicating has conformity between them [15].

Based on Table 1 shows the suitability of the process of learning the curriculum with geography skills, as well as on aspects of the assessment as it also measures the skills of geography as seen from the aspect of attitude, knowledge, and skills of learners. Thus theoretically it between curriculum subjects geography by geography skills means subjects geography curriculum is appropriate all aspects of geography skills.

\section{Relevant Research}

Logayah research: relationship between the perception of professional competence of teachers and the interests of learners with geographic skills. The result there is a tendency professionalism of teachers was a contributing factor to the geographical skills of learners. The variable interest of learners towards being categorized as a geography lesson and variable geographical skills of the students showed a trend which is still low [27].

Daryoko research [14] and Mintowati [14] explains that in a geography lesson, students only use the book as a primary learning resource. Based on these findings can be seen teachers are also less stressed the importance of mastering the skills of geography. As a result, learner's geography skills are underdeveloped.

Similarly, the findings of the research Suhardono [28] it is known that the practice of ratings based curriculum, 2013 in Klaten regency views of proficiency of teachers in preparing the assessment instrument rated is still not good. As a result, learners feel less interested and quickly get bored in learning, and do not stimulate the curiosity of students.

Utami research on geography-based learning curriculum worksheet can increase the use of creative content and build geography skills [14]. This worksheet method is one application of active learning design with a scientific 
approach. The goal is that students can gain meaningful learning experiences for him so that the learning experience will imprint in the minds of learners. To improve the knowledge and skills of geography, the material in the worksheet also contains facts, data, and maps relating to the material discussed. The results showed that the use of the worksheets in geography learning can improve the skills of geography. This increase can be seen from some of the aspects covered in the worksheet as their command on the learners to demonstrate the ability to draw maps, data analysis capabilities, as well as knowledge of geography is seen in the ability to ask, active in group discussions and express their opinions. This increase is due to more active learners, to feel interested and not bored.

Based on these studies it can be seen that in general the assessment phase of the achievement of the skills of geography students in the subjects of geography in Indonesia is influenced by the competence of teachers, learning model applied by teachers, teaching materials used, as well as the motivation of teachers to students about the importance of mastering geography skills. If a teacher has the ability to deliver and manage interactive lessons for students, then students will be interested and expected capabilities or competencies geography skills will increase.

\section{The Relationship between Literature Findings with Knowledge Assessment of Learners}

Based on literature studies on previous, described in broad outline the geography of knowledge assessment in Indonesia when seen in terms of concept, it can be said to correspond to the geography of the skills that have been put forward by Bednarz et al. This can be seen in the Table 1, which has been described previously. The learning steps are accordance with the steps of geography skills. In any instructional practices, in accordance with the rules set by the minister of education, the teacher in the learning while doing the assessment of learners.

Theoretically geography learning assessment in not only assessing aspects of knowledge alone but also assess aspects of attitudes and skills aspects. In geography teaching practices using a variety of valuation techniques as follows [26]:

1. Assessment of the attitude consists of

a. Observations; through observation of what is done by learners in learning geography.

b. Self-assessment; learners assess themselves regarding how to progress in learning what difficulties he faced and others.

c. Peer assessment; learners assess other colleagues in learning.

d. Journals, teachers noted the behavior of learners well.

2. Assessment of knowledge consists of:

a. Written test; a test that because the form of writing as well as in the answer also in writing.

b. Oral tests; tests conducted by the oral method (question and answer) between teachers and learners.

c. Assignment; the teacher gives the task given to the learners.

3. Assessment of skills comprising:

a. Practice test; the teacher asks students to practice aspects of geography that need practice.

b. The project; learners are given the task to create a project in the field of Geography.

c. Portfolio; contains the set of tasks learners in a learning period.

Table 1. Geography Skills and Learning Process Curriculum

\begin{tabular}{|c|c|c|c|}
\hline \multicolumn{2}{|r|}{ Geography Skills } & \multicolumn{2}{|r|}{ Learning Process Curriculum } \\
\hline Step & Explanation & Step & Explanation \\
\hline \multirow{2}{*}{$\begin{array}{l}\text { Asking } \\
\text { Geographic } \\
\text { Questions }\end{array}$} & \multirow{2}{*}{$\begin{array}{l}\text { This ability is related to the ability and the desire to ask } \\
\text { questions, speculate and answer statement of why } \\
\text { something exists somewhere, and why they were there. }\end{array}$} & Observing & $\begin{array}{c}\text { Viewing Event learners to read, listen, listen, } \\
\text { and see (without or with a tool). Competencies } \\
\text { developed to train seriousness, rigor, looking for } \\
\text { information. }\end{array}$ \\
\hline & & Asking & $\begin{array}{c}\text { students asking questions about information that } \\
\text { is not understood from what is observed or } \\
\text { questions to gain additional information about } \\
\text { what is observed. }\end{array}$ \\
\hline $\begin{array}{l}\text { Acquiring } \\
\text { Geographic } \\
\text { Information }\end{array}$ & $\begin{array}{l}\text { Capabilities in obtaining geographic information including } \\
\text { show locations, collecting data, observation and recording } \\
\text { information, reading and interpreting maps and } \\
\text { representations of space and other places, interviews and } \\
\text { using statistical methods. }\end{array}$ & $\begin{array}{l}\text { Trying/collecting } \\
\text { information }\end{array}$ & $\begin{array}{c}\text { Students are asked to do experiments, read } \\
\text { sources other than textbooks, observing the } \\
\text { objects/events /activities, interviews with } \\
\text { informants }\end{array}$ \\
\hline $\begin{array}{l}\text { Organizing } \\
\text { Geographic } \\
\text { Information }\end{array}$ & $\begin{array}{l}\text { Data that has been collected is organized or arranged and } \\
\text { presented for analysis and interpretation. Data should be } \\
\text { compiled systematically. }\end{array}$ & \multirow[b]{2}{*}{ Associating } & \multirow{2}{*}{$\begin{array}{l}\text { Learner's process information that has been } \\
\text { collected either limited results of collecting } \\
\text { activities / experiments and the results of the } \\
\text { activity observed or information gathering } \\
\text { activities. }\end{array}$} \\
\hline $\begin{array}{l}\text { Analyzing } \\
\text { Geographic } \\
\text { Information }\end{array}$ & $\begin{array}{c}\text { This ability is related to looking for patterns, relations } \\
\text { Social Science, and interrelations Social Science. Learners } \\
\text { analyze and interpret information, related patterns, and } \\
\text { processes. }\end{array}$ & & \\
\hline $\begin{array}{l}\text { Answering } \\
\text { Geographic } \\
\text { Questions }\end{array}$ & $\begin{array}{l}\text { Based on previous abilities that have been done, then the } \\
\text { learner's ability to answer geography questions expected to } \\
\text { be able to generalize from the findings. }\end{array}$ & Communicating & $\begin{array}{l}\text { Delivering the observations, conclusions based } \\
\text { on the analysis of oral, written, or other media. }\end{array}$ \\
\hline
\end{tabular}


In the valuation technique used contains aspects assessed in learning geography. In every aspect assessed the teachers can actually be more specialized aspects of measuring the skills of geography. But in practice sometimes teachers are still difficulties in assessing aspects of attitudes and skills. Teachers more emphasis on knowledge assessment although these two aspects (attitudes and skills) as important as the knowledge aspect. Teachers' understanding of geography skills is still low, so the teacher does not emphasize the mastery of skills geography. As a result, students lack knowledge about geography skills. Therefore, teachers are advised to understand more about geography skills. The goal is to be applied in learning geography (included in the assessment process) so that learners know, understand, and be able to apply the skills of geography.

\section{Conclusion}

1. Theoretically assessment of learning outcomes geography subjects in Indonesia it is appropriate or already measure aspects of geography skills.

2. In terms of practice, achievement geography skills of students in the subjects of geography in Indonesia is influenced by the competence of teachers, learning model applied by teachers, teaching materials used, as well as the motivation of teachers to master the skills related to the importance of geography.

\section{Acknowledgements}

The author would like to express her sincerest gratitude to Postgraduate School Universitas Pendidikan Indonesia especially the Geography Education Department, for all the support they have given.

\section{References}

[1] Kumar S, Ahmad S. Meaning, aims and process of education[J]. School of Open Learning, 2008.

[2] Yero, Judith Lloyd, "The meaning of education, teacher's mind resources." Retrieved on 14, 2009.

[3] Peters, R.S., The Concept Of Education, Routledge, 2002, [e-book] Available:

http://www.imd.inder.cu/adjuntos/article/595/The\%20Concept\%2 0of\%20Education.pdf.

[4] Jones, Cheryl A., Assessment for Learning, Newnorth Ltd, 2005, [e-book] Available: http://dera.ioe.ac.uk/7800/1/AssessmentforLearning.pdf.

[5] Goode, Kevin et al., “Assessment for Learning," EFTO VOICE, 21-24, March 2010. [Online]. Available: http://www.etfo.ca/Resources/forTeachers/Documents/Assesment \%20for\%20Learning.pdf Accessed Oct. 21, 2016, 2010. pp. 21.

[6] Nitko, Anthony J. and Brookhart, Susan M., Educational Assessment of Students. 5th Edition. Pearson Meriill, Boston, 2007, pp. 4-7.

[7] Shambaugh, Neal and Magliaro, Susan G., Instructional Instructional Design: A Systematic Approach for Reflective Practice, Pearson Education, Inc., Boston, 12, 2006.

[8] Bednarz, Sarah Witham, et al., Geography for Life National Geography Standards 1994: Geography Education Standards Project. National Geographic Research \& Exploration, Washington, D.C., 1994, 30-44.
[9] Winter, Christine, "Geography and Education I: The State of Health of Geography in Schools", Progress in Human Geography, 33(5), 667-676, 2009.

[10] Suharyono and Amien, Moch. Pengantar Filsafat Geografi. Proyek Pembinaan dan Peningkatan Mutu Tenaga Kependidikan, Jakarta, pp. 235-239, 1994.

[11] Maryani, Enok, Pembelajaran Keterampilan Sosial dalam Pembelajaran Geografi, Universitas Pendidikan Indonesia, 2009. [E-book] Available:

http://file.upi.edu/Direktori/FPSOCIAL SCIENCE/JUR._PEND_GEOGRAFI/196001211985032ENOK_MARYANI/social_skill_geog_1.pdf.

[12] Kementerian Pendidikan dan Kebudayaan. Silabus Mata pelajaran Geografi Sekolah Menengah Atas/Madrasah Aliyah (SMA/MA). Kementerian Pendidikan dan Kebudayaan, 2016. [E-book]. Available:

http://www.kurikulum2013.xyz/p/silabus-mata-pelajaran-mapelgeografi.html.

[13] The Ontario Public Service. The Ontario Curriculum Grades 11 and 12 Canadian and World Studies: REVISED. Queen's Printer for Ontario, 2015. [E-book]. Available: http://www.edu.gov.on.ca/eng/curriculum/secondary/2015cws11a nd12.pdf. [Accessed Oct. 21, 2016].

[14] Utami, Wiwik Sri, et al., "The Effectiveness of Geography Student Worksheet to Develop Learning Experiences for High School Students," Journal of Education and Learning, 5(3), August, 316-318, 2016.

[15] Kementerian Pendidikan dan Kebudayaan, Peraturan Menteri Pendidikan dan Kebudayaan Nomor 69 Tahun 2013 Kompetensi Dasar dan Struktur Kurikulum SMA/MA, Kementrian Pendidikan dan Kebudayaan, 2013. [E-book]. Available: http://repository.unand.ac.id/20951/1/permen_tahun2013_nomor6 9.pdf.

[16] Beets, Peter A.D. and Grange, Lesley L.L. Le. Has Geography Curriculum Reform in Post-Apartheid South Africa Strengthened Continuity and Progression? South African Geographical Journal 90 (2) 68-79, 2008.

[17] Stewart, Rev. Kensey Johns. Geography for Beginners. Rare Book Collection, University of North Carolina at Chapel Hill, 1864. [Ebook]. Available: http://docsouth.unc.edu/imls/stewart/stewart.html

[18] Kotlyakov, V. and Kunakhovich, M. Elsevier's Dictionary of Geography. Elsevier, Amsterdam, 2007.

[19] Mccoll, R.W. Encyclopedia of World Geography. Facts on File, Inc, New York, 2005.

[20] Ünlü, Mehmet. The Level of Realizing Geographical Skills in Geography Lessons. Kuram ve Uygulamada Eğitim Bilimleri. Educational Sciences: Theory \& Practice - 11(4). Autumn. p. 2166-2172, 2011.

[21] Houwer, Jan De, et al. What is Learning? On The Nature and Merits of a Functional Definition of Learning. Psychon Bull Rev. Psychonomic Society, Inc. 2013 [e-book] Available: https://ppw.kuleuven.be/okp/_pdf/DeHouwer2013WILOT.pdf.

[22] Reinfried, Sibylle, and Philippe Hertig. "Geographical Education: How Human Environment-Society Processes Work."Encyclopedia of Life Support Systems (EOLSS), 2011.

[23] Prince Edward Island Department of Education and Early Childhood Development Holman Centre. GEO531A-World Geography Curriculum Guide, Queen’s Printer for Ontario, 2011. [E-book]. Available: https://www.princeedwardisland.ca/sites/default/files/publications/ eelc_geo531a.pdf.

[24] The State of Queensland (Queensland Studies Authority). Geography Senior Syllabus. Queensland Studies Authority Queensland, 2007. [E-book]. Available: https://www.qcaa.qld.edu.au/downloads/senior/snr_geography_07 _syll.pdf.

[25] Barwinek, Grażyna. Variety of Assessment Forms in Teaching Geography. Prace i Studia Geograficzne, T. 48, ss. 211-219, 2011.

[26] Kementerian Pendidikan dan Kebudayaan. Inspirasi Pembelajaran dan Penilaian Sekolah Menengah Atas/Madrasah Aliyah (SMA/MA) Mata Pelajaran Geografi. Kementerian Pendidikan dan Kebudayaan, 2016. [e-book] Available: https://www.scribd.com/doc/317048506/inspirasi-pembelajarandan-penilaian-geografi-170216-pdf. 
[27] Logayah, Dina Siti, "Hubungan antara Persepsi Kompetens Profesionalisme Guru dan Minat Peserta Didik dengan Ketrampilan Geografi”. Gea, 11(2), 150-162, October 2011.
[28] Suhardono, Sapta. "Evaluasi Implementasi Kurikulum 2013 pada Pembelajaran Geografi SMA di Kabupaten Klaten,” Geo Educasia - S1. Vol. II, 2014. 